\title{
Financing System of USSR University Libraries
}

\begin{abstract}
University libraries in the Soviet Union are centrally financed by allotments in the state budget. Governmental guidelines are used in determining staff size and salaries, acquisitions, building improvements and construction, and other capital and operating expenses. Flexibility is provided for the varying functions and local conditions governing each university library, however, and local library management is responsible for preparing budget estimates.
\end{abstract}

$\mathrm{T}$ ARE 824 INSTITUTIONS of higher education in various subject fields with about five million students in the USSR today. There has been a fourfold increase in the number of students during the past twenty years.

Among these institutions, universities occupy a place of special importance. Those of Vilnius (1579), Moscow (1756), Tartu (1802), and Kharkov (1805) are some of the oldest. In 1913 only ten universities existed. ${ }^{1}$ The majority of them were founded after the October Revolution-in 1947 there were thirty universities, in 1961 forty-one, and in 1972 students were accepted into fifty-seven universities. ${ }^{2}$

In the entire library system of higher education, university libraries perform a significant role. They hold vast and specially selected book stocks, corresponding to a particular field of knowledge; each library averages over a million volumes. The number of readers in these libraries is generally very large. The role of university libraries in educational work as well as in scientific re-

This article is a revision of a paper presented by the authors at the 39th IFLA Congress, Grenoble, 1973. search is acknowledged in Soviet literature on higher education. Many operational problems of these libraries-e.g., their position in the national library system, rationalization of their structure, book acquisition, use, and preservation of stocks, etc.-have, time and again, been raised in the Soviet press. ${ }^{3}$ Though various aspects of university libraries have been discussed in the foreign press as well, their financial problems have practically never been dwelt upon in these articles. ${ }^{4}$

The entire financial system of the Soviet Union is concentrated in the hands of higher governmental bodies of the USSR; consequently, the libraries are also provided with a firm financial base. Expenditures concerning the maintenance of university libraries are included in state budgets in conformity with the statutes on education and statutes regarding budgets of higher institutions. Structurally, the library budget is part and parcel of the general university budget.

In universities it is the rector's duty to authorize expenditures, exactly in accordance with the provisions of the budget, as and when necessary. The library budget for the calendar year is 
prepared by the director of the library by a given date, and is sent for approval to the rector and then to the Ministry of Higher and Special Secondary Education of the republic.

All the expenses in such a budget are distributed under two headings: current and capital. Current expenses are the socalled operational expenses, which are directly associated with the implementation of basic library functions (e.g., acquisition of books and periodicals, publishing catalog cards, information material, etc.), and the administrative and other economic expenses (e.g., maintenance of library staff, office expenses, and others).

The estimate for operational expenses is prepared by means of a standard method which guarantees uniformity in the financing of libraries of the same category, simplifies the technique of calculation of estimates, facilitates analysis of implemented estimates of previous years, and provides a means of verification of expenditures as to the proper and economical utilization of the finances provided. ${ }^{5}$ The extent of provisions for operational expenses for a university library depends on the number of students studying at the university and expenditure norms. These norms are flexible and vary in different universities on the basis of local conditions and the specific character of the activities of each individual library. This is felt to be a feasible approach as the expenses regarding acquisition of books (including textbooks) are based not only on the number of students but also on the subjects taught at the university and the range of scientific research, how long the library has been functioning, the nature of the location of the library such as the proximity of other libraries, etc. Hence, the figures cited below represent only a few examples that present a general idea of such norms. In Vilnius University, for example, 8 rubles are allotted for every regular student, 5 rubles for an evening student, and 3.5 rubles for an external student; and in Tartu University, 12 rubles for every external student and 8 rubles for every regular and postgraduate student per year. Operational expenses at Tartu in 1972 were 75,000 rubles, from which 57,000 were spent on the acquisitions of books and journals. It should be noted that the average price of a local book is from 0.5 to 0.6 rubles. ${ }^{6}$ Hence, financial resources available to Soviet university libraries for buying books are much greater than those of the university libraries of other countries. ${ }^{7}$ This also explains the exceptionally quick growth rate for book stocks in Soviet libraries. In 1912 there were only four university libraries, with a stock of 200,000 volumes. In 1967, there were forty-four university libraries: only one possessed only 200,000 volumes; all the rest together held stocks of more than 56 million volumes. ${ }^{8}$ The annual increase in the stocks of university libraries averages approximately 5 percent.

University libraries attach special importance to the acquisition of educational literature for students. The average number of copies of any given textbook acquired per student is constantly increasing. Whereas in 1959 it was regarded as normal to purchase one copy of a textbook for every five students, in 1969 the standard was one textbook for every three students. ${ }^{9}$ Depending on their specific nature, in certain university libraries, this number is considerably higher. In Saratov University, for example, for 125 of the 142 subjects taught in natural sciences, one copy of every textbook is provided for each student; in 8 subjects this ratio is $1: 2$, and in 5 subjects it is $1: 3 .^{10}$ This tendency to provide a book for every student as well as every reader can be observed in all universities.

Educational literature ages and wears out rather quickly; consequently edi- 
tions are continuously being removed or updated. Thus the percentage of educational publications in the general stocks is not very large and, on the average, does not exceed 14 percent. ${ }^{11}$

University libraries constitute an important part of national book resources in the Soviet Union. Replenishment of their stocks is coordinated on an overall supply basis with other regional and republic libraries in accordance with their special interests. University libraries are also incorporated into the all-republican Inter-Library Book Loan System. ${ }^{12} \mathrm{Li}$ braries of new universities receive books and periodicals published in previous years from the book-exchange stocks of other libraries. By its decree of 5 January 1959, the Council of Ministers of the USSR has granted the right to all organizations to transfer their unused books, free of charge, to those libraries that need them. ${ }^{13}$

The average book stock per student in Soviet university libraries is 125 volumes. This average could be said to be comparable to the theoretical norm laid down in many countries, though it is higher than the actual average book stock per student observed in many foreign university libraries. ${ }^{14}$

The structure and staff of an institution of higher learning are set up according to several guidelines: amount and nature of work in the library; number of regular, evening, and external students; quantity of book stocks; and the specific nature of subjects taught in these institutions. A university library is a complex organ, containing several reading halls, lending departments, branches, and subsidiary libraries. A typical design exists, a list of standards and regulations pertaining to a higher institution library as laid down by the Ministry of Higher Education by their order dated 17 April 1962. On the basis of the number of students studying at the corresponding universities and the size of their book stocks, all these libraries are divided into five groups: (1) more than 10,000 students attending; (2) 5,000 to 10,000 students, and book stocks exceeding 1 million volumes; (3) 3,000 to 5,000 students, and stocks over 250 ,000 volumes; (4) 1,000 to 3,000 students, and 200,000 volumes; (5) 1,000 or fewer students. Expenses for staff maintenance depend not only on the group the library belongs to and its structure but also on the number of staff and their basic salary grades. In order to introduce uniformity concerning the number of staff in libraries, the Central Ministry of Higher Education has laid down certain specifications in a decree of October 1968. These are based on a library's grouping, its book stocks and the number of its readers. For example, libraries in the second group with 6,000 to 7,000 readers are assigned sixty-four library workers; those having 9,000 to 10,000 readers are assigned seventy-eight. In addition, for every 100,000 volumes exceeding the 500,000 figure an extra bibliographer is assigned, and for every million books over the initial one million, one extra chief bibliographer is envisaged. $\mathrm{Li}$ braries in the third group with 3,000 to 4,000 readers have thirty-seven workers; those having 6,000 to 7,000 readers, forty-eight workers; and an extra bibliographer is assigned for every additional 100,000 volumes over and above 300,000 volumes.

In keeping with the special position that certain large university libraries, with rich and rare collections of books and manuscripts, hold in the national library system, their staff is recruited on an individual basis. These libraries are the research libraries of Moscow, Leningrad, Kazan, Tomsk, Saratov, Rostov, Irkutsk, Kiev, Kharkov, Vilnius, Tartu, and Tashkent.

Since 1965 a uniform salary scheme for library workers in all departments, institutions, and organizations has been in operation. In Soviet libraries, work- 
ers are divided into two categories: (1) management workers and specialists, and (2) bibliographers and librarians. To the first group belong library directors, assistant directors, heads of branches, departments, sections, and sectors, learned secretaries, editors, and head librarians and bibliographers. Because the workload of management workers is, to a certain extent, dependent on the functions and volume of library work, their salaries are differentiated from those in the above group by 10 to 20 percent. The salaries of librarians and bibliographers are determined by the post occupied, educational qualifications, and length of service in the library. Knowledge of foreign languages and their use in everyday work can increase the basic salary by 10 percent for one language, and 15 percent for two or more languages. ${ }^{15}$

Financial provisions for paid holidays and for sick pay or temporary disability are incorporated in the general annual wage estimate. Annual paid holidays for university library employees amount to twenty-four working days; for those with postgraduate degrees it is thirty-six; and for those with doctoral degrees, forty-eight working days. ${ }^{16}$

With an increase in the number of readers and books, the university library staff also constantly increases. While drawing up salary estimates, library management, in consultation with the rector of the institute, considers an increase in staff, in order to make the necessary provision for such an increase in the wage fund estimate.

In recent years, university libraries have begun to pay special attention to rationalization of employee working time. Matters regarding improvement in planning for organization and standardization in work are being dealt with at present. Research dealing with these problems has been conducted at Kharkov, Leningrad, and other universities. $^{17}$

Many university libraries have sub- sidiary book stocks, where office assistants, not librarians, work. For instance, in 1970 the Research Library of Saratov University had fifty-one subsidiary libraries at various faculties of the university served by office assistants of the respective faculties. Their stocks amounted to 92,881 books (i.e., 4 percent of the aggregate stocks of the library), and the number of books issued to readers was 88,109 (i.e., 3.5 percent of the aggregate book issue) ${ }^{18}$

Office and other expenses, e.g., telephone, postal expenses incurred by the interlibrary loan department for dispatching books, heating and lighting, business tours of the staff to other libraries, expenses for procurement of library equipment and general stores, etc., are incorporated into estimates.

Estimates of capital expenses for major repairs and reconstruction of library buildings are made with the aid of drawings or plans submitted in advance, and these are checked and confirmed by the technical board. Pricing is calculated at existing rates. ${ }^{19}$ Technical documentation and estimates are accepted by the planning organization only on order from the university.

Plans and estimates for new buildings are based on standard rates, wages, and tariffs. Basic norms for building projects are contained in the Instructions of State Building Board of the USSR. According to the norms laid down for university libraries, ten to twelve seats are assigned for every 100 students in reading halls; 2.2 square meters floor space per seat in the reading halls for undergraduate students, and 3 square meters for postgraduate students; 2.2 square meters per 1,000 volumes in depositories, and 4.4 square meters per 1,000 volumes on open bookshelves.

In recent years, several new buildings have been designed and built for various university libraries: Tbilisi University library building with a capacity for 3 million volumes and reading halls 
seating 1,200 readers; Kazan University Library with a depository for 4 million books; Tartu University Library with a capacity for 5.7 million volumes and 1,100 seats in reading halls with a budget estimated at 5.5 million rubles. ${ }^{20}$

As a rule, the administrative supply department of the educational institution is responsible for major repairs and new construction of library buildings. Funds for capital investment are provided in the budgetary plans of the institution and are approved at the republican governmental level.

Thus, the Soviet university library, as an essential constituent of the university, is provided with regular finance in state budgets. The library budgets are based on generally prescribed norms, which are not final but sufficiently flexible: they provide for standard expenses as well as contain provisions for differentiation by varying local conditions and specific requirements and characteristics of each individual library. Library management takes an active part in planning library expenditures and formulation of budgetary estimates.

The principle of democratic centralism-backbone of the entire Soviet financial system-is translated into reality even here. The problem of complex long-term planning of expenditures is one of the most difficult ones in library management. At all-union levels of finance, the practice of drawing up such complex long-term plans for all departments and organizations and coordinating their activities is becoming more widely acknowledged. From 1972 to 1974, a long-term prognosis of the USSR's growth of library activities for the next fifteen to twenty years has been made on the basis of research being carried out by some of the country's leading university libraries.

\section{REFERENCES}

1. S. K. Vilenskaya, "Universitetskie biblioteki SSSR $\mathrm{i}$ ikh mesto $\mathrm{v}$ sisteme sovetskikh bibliotek," Biblioteki SSSR 12:58 (1959).

2. Spravochnik dlya postupayushchikh v vysshie uchebnye zavedeniya SSSR v 1972 godu (Moscow, 1972), p.63-89.

3. Vilenskaya, "Universitetskie biblioteki," p. 56-73; T. P. Pyshnova, "K voprosu o strukture universitetskikh bibliotek," Biblioteki SSSR 21:34 47 (1962); T. P. Pyshnova, "Obsluzhivanie $\mathrm{v}$ chital'nykh zalakh universitetskikh bibliotek," Biblioteki SSSR 25:72-87 (1964); K. M. Romanovskaya, A. B. Paperno, and F. N. Pashchenko, "Tsentral'naya i fakul'tetskie biblioteki universiteta," Nauchnye $i$ teknicheskie biblioteki SSSR 8:23-28 fll. (1969).

4. L. Vladimirov, "Biblioteka gotovitsya $k$ svoemu 400-letiyu," Byulleten' YUNESKO dlya bibliotek 2:96-98 (1969); Vladimirov, L. "The Accomplishments of University Libraries in the Soviet Union," Library Trends 4:558-82 (1964).

5. M. B. Bogachevskii, Finansy $i$ kredit SSSR (Moscow, 1969), p.162.

6. I. M. Frumin, Organizatsiya raboty sovetskoi biblioteki (Moscow, 1969), p.98.

7. K. V. Penna, "Finansirovanie bibliotek i sluzhb dokumentatsii," Byulleten' YUNESKO dlya bibliotek 5:254 (1968); Jahresbericht der Universitätsbibliothek Kiel, 1970 , p.5.

8. Biblioteki SSSR obshchestvenno-politicheskogo, filiologicheskogo $i$ iskusstvovedcheskogo profilya. Spravochnik (Moscow, 1969), p.83-104.

9. Vilenskaya, "Universitetskie biblioteki," p.62; Romanovskaya, Paperno, and Pashchenko, "Tsentral'naya i fakul'tetskie biblioteki," p.24.

10. V. S. Prygina, "Obespechennost' studentov uchebnikami v bibliotekakh vuzov Saratova," Opyt raboty nauchnoi biblioteki SGU 18:32 (1972).

11. Vilenskaya, "Universitetskie biblioteki," p. 62 .

12. "Polozhenie o edinoi obschegosudarstvennoi sisteme mezhdubibliotechnogo abonementa v SSSR," Biblioteki SSSR 43:106-11 (1969).

13. Rukovodyashchie materialy po bibliotechnomu delu. Spravochnik (Moscow, 1968), p.16-17.

14. R. Kluth, Grundriss der Bibliothekslehre (Wiesbaden, 1970), p.240.

15. Rukovodyashchie materialy, p.229-52. 
16. B. D. Lebin and G. A. Tsypkin, Prava rabotnika nauki (Moscow, 1971), p.135.

17. M. P. Kiryukhin, "Nauchnaya organizatsiya truda v universitetskoi biblioteke," in Vsesoyuznaya konferentsiya "Kniga $i$ progress" (Vilnius, 1970), p.40-62; K. M. Romanovskaya and Zh. S. Shadrina, "Voprosy primeneniya teorii massovogo obsluzhivaniya," Nauchnye $i$ tekhnicheskie biblioteki SSSR 7:9-12 (1969).

18. Nauchnaya biblioteka Saratovskogo gosuni- versiteta v 1970 godu (Saratov, 1971), p.6, 81, 99.

19. S. P. Chernikov, Finansirovanie kapital'nogo remonta (Moscow, 1972), p.31.

20. F. Pashchenko and V. Vinogradov, "Praktika proektirovaniya i stroitel'stva krupnykh bibliotek v SSSR," Byulleten' YUNESKO dlya bibliotek 6:353-54 (1970); L. Peep, "Valmis raamatukoguhoone tehniline projekt," Edasi 8:7 (1971). 